\title{
THE PORTABILITY OF ALTMAN'S Z-SCORE MODEL TO PREDICTING CORPORATE FINANCIAL DISTRESS OF SLOVAK COMPANIES
}

\author{
Martin BOĎA, Vladimír ÚRADNÍČEK \\ Quantitative Methods and Information Systems Department, Faculty of Economics, \\ Matej Bel University in Banská Bystrica, Tajovského 10, 97590 Banská Bystrica, Slovakia
}

Received 11 April 2016; accepted 31 May 2016

\begin{abstract}
The paper challenges the widespread use of Altman's bankruptcy formula known as the "Z-score model" in Slovak corporate practice and comes with the goal to verify its usability in the Slovak economic environment. To this end, a definition of financial distress is adopted that summarizes weaknesses of Slovak enterprises stemming particularly from liquidity drain and operating losses. The verification juxtaposes three variants of the Z-score model and assesses their prediction ability using a data set of Slovak enterprises for the period from 2009 until 2013. Both the original 1968 Z-score model and the revised 1983 Z-score devised for the US economic environment are compared with the Z-score model re-estimated to the Slovak data copying the methodological procedure of Altman. The results indicate that Altman's bankruptcy formula is portable into the Slovak economic conditions and useful for predicting financial difficulties in view of the adopted definition of financial distress. Altman's original and (especially the) revised formulation of the Z-score model are preferable if overall classification accuracy is the main interest. Finally, it is advisable to re-estimate the coefficients of the Z-score model if financially distressed enterprises are the focus and the goal is to classify distressed enterprises as best as possible.
\end{abstract}

Keywords: Altman's bankruptcy formula, Slovak enterprises, financial distress, classification accuracy, true positive rate.

JEL Classification: G33, M40.

\section{Introduction}

This paper's thematic orientation revolves around Altman's bankruptcy formula. This notorious bankruptcy prediction model popularized as the "Z-score model" has found application in various fields of finance where knowledge of an enterprise's future financial condition is perceived vital. Although devised almost half a century ago, Altman's Z-score model continues to be encountered and used routinely in a multitude of business situations, which encompass corporate financial analysis made by enterprises for the purpose

Corresponding author Martin Boda

E-mail: martin.boda@umb.sk 
of managerial decision-making. It is also made by investors for their investment decision, credit assessment of corporate customers carried out by commercial banks, or the on-going concern assessment of corporate clients undertaken by auditors. A peculiar trait of the model is that it was developed for the dated environmental conditions of the US economy, and yet the model is used on an international basis outside its domestic environment. In such a way, Altman's model is used also in Slovak corporate practice and is very popular to both theorists and practitioners of corporate finance, which is striking and odd as there are a number of reasons provoking caution or even outright opposition to its use.

The underpinning of Altman's Z-score model is the belief that it is possible - on the basis of past information embedded and represented in financial indicators (such as liquidity, activity, capital structure, or profitability ratios) - to predict an enterprise's future financial distress and in such an implicit way to measure its financial health. Committed to this task, Altman, in 1968, made use of 5 financial indicators computed for a limited non-representative sample of US enterprises so as to develop a model in the framework of a multi discriminant analysis (see the original paper: Altman 1968). Despite the methodological and technical limits in the 1960's and the limitations of the data samples available, the model exhibited high accuracy rates for both the estimation and the hold-out sample and attained a high level of prediction to the actual conditions of the US corporate practice of the 1970's. Altman is credited with being the first to set up a rigorous and formal bankruptcy prediction model in a multivariate framework (see e.g. Dimitras et al. 1996: 498; Delina, Packová 2013: 101). It is perhaps the main reason that the model proliferated and continues to be a standard bankruptcy prediction model for US manufacturing companies and others as well. As we consider the present period, its usability had been extended beyond the US non-manufacturing companies to include the entire US economic environment and then became internationalized. In this respect, a version of Altman's Z-score model developed again by Altman (1983) and known as the "revised Z-score model" is oft referred to in this paper and contrasted with the "original" Z-score model.

Altman's Z-score model has been applied to Slovak corporate practice without any regard to the serious methodological limitations of its sensible use. Some examples are listed here in this paper. In addition, the aspects of its use in application and misuse are not clear as the formula was elaborated for the purpose of bankruptcy prediction, whereas it is usually interpreted in reference to financial distress. That being so, this problem appears to be rather fortunate as there are views, some theoretical and others empirical, that this model should be used for predicting financial distress rather than bankruptcy itself (e.g. Gilbert et al. 1990: 169; Grice, Ingram 2001; Grice, Dugan 2001).

Noting that bankruptcy models are better suited to the task of predicting financial distress and building on this premise still leaves uncertainty as to whether Altman's Z-score model should be judiciously applied to Slovak economic conditions and as such, its appropriateness must be verified. This paper does not attempt to develop a new bankruptcy model for predicting financial distress in the Slovak economic environment; in this respect, the initiative is left to others (see e.g. Chrastinová 1998; Zalai 2000; Gurčík 2002). With regards to all the limitations that are associated with the current use of this model, the goal of the paper is to verify whether it is useful for predicting financial distress of Slovak 
enterprises. Using a data set of Slovak enterprises for the 2009-2013 period, the verification proceeds on two tracks and is based on three alternative Z-score model representation. One representation addressing performance predictions is the model with an original coefficients as was estimated from US data by Altman himself (Altman 1968), whilst another representation is the revised model with updated coefficients estimated from the same data set also made by Altman (1983). Eventually, the third representation is the model with the coefficients estimated from Slovak data following Altman's methodological procedure. As is the case with the majority of studies of this sort (cf. e.g. Balcaen, Ooghe 2006: 75) concerning Altman's Z-score estimation, the sample of enterprise data for modelling does not originate as a random draw, which is the reason that statistical testing is avoided and not attempted here.

The results indicate that the Z-score models based on Altman's methodology do have some merit in predicting distress of Slovak enterprises. The Z-score models devised by Altman $(1968,1983)$ for US manufacturing enterprises should be used in the Slovak economic conditions only when overall accuracy is of central interest (i.e. when it is important to classify enterprises correctly regardless of whether they are actually distressed or not). It is particularly the revised Z-score model that may be recommended for use in this classification context. However, if the objective is to mainly identify distressed enterprises (and misclassifications of non-distressed enterprises are not a nuisance), then it is appears as advisable to re-estimate the Z-score model and to found the classification procedure on the new estimated classification rule. These findings confirm the fact that Altman's Z-score model is portable and robust for the Slovak economic environment.

Before going into updating the formula of the Z-score model with the use of Slovak data and conducting the intended verification, two stopovers are necessary. Some space must be reserved for presenting the methodological elements of the model, and some attention must be focused on discussing applicability of the model in the Slovak conditions and its interpretation. The body of the paper is thus organized into three other sections: a section expositing the model and particularizing the historical circumstances under which it was developed; a section cautioning against its mechanical use in the Slovak economic conditions whilst suggesting an appropriate interpretation that should be given to the model; and a section presenting the results of the intended verification. Finally, the last part of the paper contains the concluding remarks an discussion.

\section{Altman's Z-score model and its alterations}

The first rigorous effort in the area of corporate bankruptcy prediction was attributed to Altman (1968) who developed a five-factor model using linear discriminant analysis (LDA). His model continues to be used nowadays with non-diminishing popularity not only it the US environment, but also in Slovak corporate practice. The model was originally developed for manufacturing enterprises with publicly traded shares, but was later improved into a model for manufacturing enterprises with shares non-listed on the capital market (see Altman 1983) and into other models including non-manufacturing companies as well (see Altman et al. 1977; Altman 2013). Nonetheless, the original model of 1968, 
known as the Z-score model or called Altman's bankruptcy formula, still appears to be the model of choice worldwide (see e.g. Altman et al. 2014: 2).

The original Z-score model assumes that the analysed enterprise is listed on a capital market and integrates in a linear fashion 5 financial indicators. Their list comprises: X1 working capital/total assets, X2 - retained earnings/total assets, X3 - earnings before interest and taxes/total assets, X4 - market value of equity/book value of debt, and X5 - sales/ total assets. All of them are constructed as ratios of items reported in financial statements or computed from available market data. Usage of the market value of equity in X4 necessitates that the entity is listed on the capital market (as it is usually equalled to the market capitalization of the entity's shares) or that this sort of information is available that goes beyond the traditional informational content of financial statements. All the other variables appearing in the definition of X1 - X5 are particular items declared in financial statements.

At any rate, the values of these five indicators are substituted into the linear function,

$$
\mathrm{Z}=1.2 \mathrm{X} 1+1.4 \mathrm{X} 2+3.3 \mathrm{X} 3+0.6 \mathrm{X} 4+0.999 \mathrm{X} 5
$$

which gives a value of the so-called Z-score. High values of the Z-score point to good financial health and low values suggest an increased probability of bankruptcy. To distinguish between financially healthy companies and companies with increased probability of bankruptcy, two cut-off values were defined by Altman in the process of the model's verification: if the Z-score is below 1.81, the analyzed entity is at risk of bankruptcy, but if the Z-score exceeds 2.99 , the analysed entity should be viewed as financially healthy. The area between 1.81 and 2.99 is interpreted as the grey area (or the "zone of ignorance") with difficulty to predict the financial status.

It is instructive to study briefly the methodological procedure that was utilized to develop the Z-score model and estimate the coefficients of the function (1). The five indicators represented in (1) were selected from a list of 22 financial ratios describing an entity's financial status in terms of liquidity, solvency, activity, profitability and leverage. Whilst modelling, Altman used LDA, and in obtaining the coefficients of (1), he used the paired sample of 33 bankrupt and 33 non-bankrupt manufacturing companies with shares listed on the capital market. Crucial in this respect, is not only the disturbingly small sample size, but also the way this sample was constructed. Starting with the sub-sample of 33 bankrupt U.S. companies listed on the capital market, which between 1946 and 1965 filed a petition for bankruptcy liquidation according to Chapter X of the National Bankruptcy Act (addressed as the Chandler Act and effective in the U.S.A. between 1938 and 1978). These companies were all medium-sized manufacturing and were each paired with a comparable U.S. medium-sized manufacturing company listed on the capital market that had not experienced bankruptcy difficulties in the investigated period of 20 years. The issue of random sampling was not performed by Altman at all (understandably due to the limited availability of data).

Later the model was modified, re-estimated and published by Altman in his monograph (Altman 1983: 120-124) in order to account for manufacturing entities non-listed on the capital market. In the process, X4 was changed into X4' defined as book value of equity/ book value of debt and under this definition its calculation does not require market data. 
Using the same data set as in the 1968 paper, the re-estimated functional then took the form:

$$
Z^{\prime}=0.717 \mathrm{X} 1+0.847 \mathrm{X} 2+3.107 \mathrm{X} 3+0.420 \mathrm{X} 4^{\prime}+0.998 \mathrm{X} 5
$$

in which $Z^{\prime}$ denotes the changed Z-score. The boundary points were subsequently changed to 1.23 (from 1.81) and 2.9 (from 2.99), otherwise, the classification rule remained intact. This model is known as the revised Z-score model, which is the name assigned by Altman himself (Altman 1983: 202). In the same monograph Altman (1983: 124) eventually extended and adapted this model for non-manufacturing entities whose shares need not be listed on the capital market. The model was named as the $\mathrm{Z}^{\prime \prime}$-score model. There have been a number of competing models proposed and estimated for the U.S. environment as well as for different economic conditions using different methodologies (see e.g. Balcaen, Ooghe 2006; Wu et al. 2010), in addition, there has been another model that was proposed by Altman et al. (1977) along the established tradition that used 7 predictors and was formulated for entities in manufacturing and retail. Implemented in the framework of LDA, this model is proprietary and designated for the purpose of credit risk assessment. It came with a trademark and was launched as the ZETA ${ }^{\varpi}$ model. Even so this second-generation model has never received the level of immense popularity as the Z-score model in its original variant.

Since then, a number of other models have been developed using sophisticated methodology surpassing the limitations of discriminant analysis and specialized to a particular country's economic conditions, it seems that the original model still prevails in predicting bankruptcy not only in the world (see Grice, Ingram 2001; Balcaen, Ooghe 2006; Atlman et al. 2014) but also for Slovakia. The following section gives some examples of overconfidence in the use of the original Z-score model in the Slovak conditions and questions the very possibility of such usage. It rather suggests an adequate interpretation of its indicative capability.

\section{Usage of the Z-score model in the Slovak conditions: limitations and interpretation}

It seems that Altman's Z-score model given by (1) and (2) is utilized frequently in the Slovak corporate practice notwithstanding the apparent methodological troubles. A number of methodological issues arise emanating from the fact that the model is even used under Slovak economic conditions (being different from those for which it was formulated) and the fact that its usage is extended to the contemporary period (irrespective of a historical gap of 50 to 70 years). Another specific - enforced by the intentional specialization of the original Z-score model in listed enterprises - is that it is implemented in mixed form combining both formulas (1) and (2). Strictly speaking, the original 1968 discriminant model in (1) is not workable without knowledge of non-market information (necessary to compute the value of X4). Yet, practitioners prefer to use this original model, in which they mechanically and nonchalantly substitute X4' for X4 keeping the coefficient values and preserving the original boundaries of the classification zones. In other words, the market 
value of equity is simply replaced by the book value and the formula in (1) is otherwise used in its fullness.

One more problem comes from the obvious incompatibility in the reporting standards carried over in financial statements that are the basis for computing the values X1 - X5 . This methodological note relates not only to the very difference between the US and Slovak accounting systems but also to the temporal discrepancies resulting from past times to the present. On the one hand, in the Slovak Republic, enterprises are required to report in compliance with the national financial accounting standards or in compliance with IFRS; on the other hand, the data used by Altman $(1968,1983)$ were calculated from financial statements reported in conformity with US GAAP. Altman's data pertained to the period from 1946 until 1966 and fully absorbed methodological updates and modifications in the US GAAP standards made effective occasionally from year to year. In effect, the methodical content of the financial ratios used by Altman $(1968,1983)$ and the information they convey differs from the content and informational value of the financial ratios of present, computable from Slovak financial statements. Therefore, a practitioner applying the original Z-score model in (1) or the revised Z-score model in (2) in an otherwise "correct" manner, makes at best an approximation and an educated guess to bankruptcy prediction.

All these points invalidate usage of Altman's Z-score model in the Slovak conditions although some of the definitional uncertainties may be to some extent mended. Despite these critical reservations, it is still possible that the model is portable and may be an aid in predicting financial health of enterprises, not only in the present period, but also in the Slovak economic conditions. Such a possibility follows from the fact that the selected five indicators, X1 to X5 (with X4 changed to X4'), possess a universally good and a priori of economic rationale in fulfilling the task of distinguishing between enterprises that are financially sound and healthy and those that are financially distressed. A justificatory account for their use in a discriminatory context is provided in depth by Altman (1968: 594-596, 1983: 106-107). The generalization of Altman's Z-score model across different time periods has been extensively studied, albeit its application has not gone beyond the US economic environment (cf. e.g. Begley et al. 1996; Grice, Ingram 2001; Wu et al. 2010; Li 2012). All the same, some researchers were interested in a possibility of applying Altman's Z-score model in the Czech economic environment (Pitrová 2011; Kopta 2009; Kalouda, Vaníček 2013) or even in the Slovak economic conditions (Zalai 2000; Gurčík 2002; Delina, Packová 2013). Notwithstanding the factors opposing this model or the research findings, corporate theorists and practitioners are oblivious and do not seem discouraged from using it for Slovak enterprises. Some selective examples are provided that Altman's model is applied on a massive scale in real practice or amongst corporate professionals.

- Altman's Z-score model is promoted within the professional community by virtue of popularizing articles advising its use in the Slovak conditions. Examples include Stolárik (1996), Zalai (1997: 21-22) or Štrangfeldová (2012: 14-16). Altman’s Z-score model is further implemented (with some other bankruptcy prediction models) in the functionalities of the Sofina Microsoft ${ }^{\oplus}$ Excel $^{\oplus}$ spreadsheet application offered on a commercial basis as a complex software tool for financial analysis (see Király et al. 2015) and its lite version complements a book on corporate financial analysis by Kotulič et al. (2010). 
- There are many instances in which Altman's formula is used for the purpose of real corporate analysis and is reported in financial statements and annual reports, partly in assessing the ability of an enterprise to continue as a going concern. This utilization of the Z-score model can be found in many annual reports of manufacturing firms (e.g. Púchovský mäsový priemysel 2014) or service providers (e.g. Dopravný podnik mesta Prešov 2015; I.S.D.D. plus 2014; Kúpele Trenčianske Teplice 2012). Regrettably, a number of examples of the sort can be found.

- An illustrious application of the revised Z-score model is encountered in the analytical materials of the Slovak Business Agency, which is a specialized non-profit organization founded by the Ministry of Economy of the Slovak Republic providing support to small and medium-sized enterprises (SMEs). In the analyses of financial performance of SMEs issued by the Slovak Business Agency (2014: 45-51; 2015: 44-51), Altman's Z-score model is exploited to consider the financial health of the segments of Slovak SMEs and its trends are scrupulously assessed. It must be admitted, though, that the Z-score model is used in these analyses in the correct format intended for private enterprises (with the revised coefficients and boundary values of the grey zone), which defies the usual practice of using the model in mixed form.

The listed applications of Altman's Z-score model are made in the belief that they are methodologically correct and that it is perfectly proper to predict bankruptcy in this way, which naturally is not correct. It must be admitted though, that incentives for such an overuse of Altman's Z-score model come sometimes from respectable sources. For instance, in their book on corporate finance, Hillier et al. (2010: 839-840) use the model for a publicly traded European enterprise, upon which they voice a well-intentioned caution that one should not take the outcome as "particularly precise". Interestingly, it is the very Altman (1983: 206) who discusses the Z-score model and concedes in his concluding notes that the model should be applied with care in practical situations.

In exacerbation to incorrect usage of Altman's Z-score model, there is an issue that it is not completely clear what it really predicts and in what respect it is helpful. In part, this relates to the difference that exists between financial distress and bankruptcy as two different notions of enterprise economic condition, although it is also connected to the empirical behaviour of the model. Recognizing that bankruptcy is a term designating a legal status for an enterprise while financial distress is a term employed to capture its worsened economic position, there is an opinion maintained e.g. by Taffler (1984), Gilbert et al. (1990) or pointed out by Grice, Dugan (2001: 154) that bankruptcy models should be viewed in a broader context of financial distress prediction. On this point Gilbert et al. (1990: 169) clarify that "bankruptcy model scores should be interpreted as descriptions of financial distress rather than as predictions of bankruptcy per se". This comes with the empirical testimony focused specially on Altman's Z-score model and delivered by Grice, Ingram (2001) who make a compelling case that "the model is useful for predicting financial distress conditions other than bankruptcy" (ibid.: 53). There are a number of occasions summarized e.g. by Altman et al. (2014: 6) on which the Z-score model is utilized for measuring financial distress or financial strength. In fact, as follows from a brief overview made by Begley et al. (1996: 283) the model happens to be chosen frequently for predicting financial distress (as opposed to 
bankruptcy). The aspect of appropriate interpretation of Altman's Z-score model is rooted in the separation of the notions of bankruptcy and financial distress from each other. To be fair, it must be said that there are empirically established arguments that financial distress and bankruptcy are separate processes driven by different factors (see e.g. Platt, H. D., Platt, M. B. 2006). The immediate consequence is that bankruptcy models are not valid in predicting financial distress, and vice versa.

Bankruptcy describes a legal status of failure resulting from insolvency whose declaration is initiated on request and sets off a formal procedure of corporate reorganization (in an attempt at a recovery program) or liquidation. In contrast, financial distress is usually understood in a broader sense as it describes a financial condition when an enterprise experiences difficulties in fulfilling financial obligations on schedule to the fullest extent or suffers from insufficient liquidity. Both bankruptcy and financial distress are associated with insolvency, yet bankruptcy is a single-event issue and commences with a formal declaration of insolvency, financial distress results from various events and ends up with declared on undeclared insolvency. Some useful discourse on the differences and relationship between financial distress and bankruptcy can be found, e.g. in Gilbert et al. (1990: 161-162, 169-170), Balcaen, Ooghe (2006: 72-73), Sun et al. (2014: 42-43). As such, financial distress is characterized technically by a number of operational indicators that are used in capturing negative events that may (and possibly) cause financial instability eventually manifested in insolvency. A conviction on suitability of these operational indicators to detect financial distress is then mirrored in the definition that operationalizes the status of financial distress. Usually this definition is adjusted to specific corporate conditions under investigation or is limited by data availability.

The sparse Slovak bankruptcy literature focuses upon bankruptcy rather than financial distress and therefore uses the judicial definition of bankruptcy to this end (e.g. Delina, Packová 2013), or tends to use a specialized definition.

- In the former case, the legal definition of financial distress according to the current bankruptcy law lays down the economic precondition for bankruptcy that a debtor is in distress if he be either insolvent (i.e. incapable of paying at least two liabilities that are 30 days overdue to more than one creditor) or overdebted (i.e. the value of liabilities to more than one creditor is in excess of the value of assets). The legal precondition is that a petition for bankruptcy proceedings be filed by the debtor himself or by any of his creditors. (Bankruptcy Act No. 7/2005 Coll., $\$ \$ 3,11$ (Zákon č. 7/2005 ...)).

- The second case is exemplified by the approach of Šnircová (1997: 16) who classifies an enterprise as financially distressed in a given year if it fails to report a positive EAT (earnings after taxes) and at the same time it shows a level of liquidity measured by the current ratio lower than 1. The approach of Šnircová (1997) seeks to establish a relationship between liquidity and financial distress in a way similar to Hrdý, Šimek (2012: 126) although these authors centred on the Czech economic environment.

Notwithstanding the territorial and economic scope of Altman's Z-score model, it is naturally questionable as to whether the model is outdated and still applies to the new economic conditions, which has changed since 1968 when the original version of the model was published. Although centred mostly on the US corporate environment, there is suf- 
ficient evidence that the model delivers a decreased predictive accuracy with more recent data and that the model's coefficients seem to be unstable in different economic periods (e.g. Begley et al. 1996; Wu et al. 2010: 35; Grice, Ingram 2001: 53; Balcaen, Ooghe 2006: 70). This observation substantiates the resulting advice to estimate the model's coefficients anew in order to reflect the ever-present environmental changes.

Referring to the quoted testimony of the empirical research that the Z-score model is more apt in identifying generally distressed enterprises than bankrupt ones, the described circumstances against its use for Slovak enterprises are further borne in mind and the paper proceeds in defiance of the logic of importability across time periods and economic environments. Its aim is then to verify whether Altman's Z-score model is, in the mixed-impure form, useful to the task of discriminating between financially distressed and financially non-distressed Slovak enterprises. What is not the goal of this paper is the development of a completely new model, even one possibly based on the five Altman's ratio indicators. The paper thus remains in proximity to the current Slovak corporate practice prejudiced in favour of Altman's Z-score model.

\section{Verification of the Z-score model for use in the Slovak conditions}

In assessing the capability of the Z-score model to predict financial distress of Slovak enterprises, the verification procedure stood upon three variants of the Z-score model that were compared in terms of their predictive performance and helpfulness in identifying financially distressed enterprises. The subject of comparison were thus

- the "original" $1968 \mathrm{Z}$-score model given in (1) with X4' forcibly substituted for X4,

- the 1983 revised Z-score model obeying in full the specification in (2),

- the newly-estimated Z-score model using X1, X2, X3, X4' and X5.

Whilst the first variant corresponds to the mixed impure form in which the model is proliferating in the Slovak corporate practice, the second variant is perhaps more appropriate and its usage is comparatively more valid if one omits a number of other methodological issues. Lastly, the third variant of the model should expectably comply with the actual environmental conditions in which Slovak enterprises operate and should therefore be found outperforming the other two models. Its inclusion to the verification conforms to the views summarized before in the preceding section that the model should be re-estimated with a new set of data. All the same, the classification performance of this triplet of variant adaptations of the Z-score model is reasonably anticipated to be less satisfactory than that of the "true" Z-score models as initially ascertained by Altman $(1968,1983)$ for the US economic environment or as found later by other researchers for the US environment in different time periods (see e.g. Altman, Hotchkiss 2006: 244).

The depth of the verification was limited by data availability and the analysis required several methodological specifications which deserve both explanation and vindication.

Before anything else, a definition of a financially distressed enterprise had to be adopted that would adequately reflect financial difficulties that distressed Slovak enterprises have to face. A total of three criteria of financial distress were formulated on the basis of the 
definitions of financial distress as legalistically established in $\$ \$ 3$ and 11 of Bankruptcy Act No. 7/2005 Coll. (Zákon č. 7/2005...) and as formulated by Šnircová (1997: 16). For the purpose of this paper, an enterprise is considered financially distressed if (a) its equity is negative, (b) its EAT is negative, and (c) its current ratio attains a value lower than 1 . All the three conditions must be satisfied in order for an enterprise to be considered financial distressed. As to the first condition, it is a simpler formulation of over indebtedness stipulated by the legal definition of financial distress (save that for reasons that are merely practical, it is not required that the liabilities in excess of assets must concern more than one creditor). The second condition highlights that in a given year an enterprise is lossmaking and combined with the first condition this criterion is instrumental in pinpointing enterprises that are in the long-run unprofitable. A negative value of equity suggests that the enterprise concerned has made over the past periods an unsustainable amount of losses (beyond the level absorbable by its assets) and a negative value of EAT then reveals that there are no sign of change and the enterprise continues to be on an adverse path of (accounting) value destruction. The ex post financial analyses elaborated by the Ministry of Economy of the Slovak Republic and by the Slovak Business Agency bear testimony to the fact that the ability to report a profit and maintain it is crucial and existential to many Slovak enterprises (cf. Ministerstvo hospodárstva Slovenskej republiky 2014: 9-10; Slovak Business Agency 2014: 11-13, 2015: 9-10). In addition, the third criterion is associated with undercapitalization, a situation in which long-term assets are covered not only by long-term liabilities but also by a fraction of current liabilities. Such a situation is in the long run not sustainable and it also implies an accounting form of insolvency. By definition, an undercapitalized enterprise is unable to liquidate all its current assets to pay off or settle all its current liabilities. A too low a level of liquidity is an impediment to honouring short-term payables and implementing investment strategies. The significance of liquidity for Slovak enterprises is discussed e.g. by Strachotová (2012: 3-4) who assesses the liquidity of the whole entrepreneurial sector in Slovakia as well.

In respect of this particular choice employed in designating a financially distressed company, it need also be noted that the first two criteria - in a manner of speaking - express the long-term aspect of financial difficulties. It is customary to define or identify financial distress on the basis of few technical indicators and many study have looked into the past fiscal periods of two or three years. Usually some variations of profitability ratios screened for the two or three consecutive periods are therein employed (see e.g. Platt, H. D., Platt, M. B. 2006: 144, 155; Asquith et al. 1994: 628). The condition of negative equity and negative EAT maps both the present situation and simultaneously provides a sufficient insight into the past underperformance. Alternatively, negative equity may be as well a result of the present period's immense loss, which is then a dependable indicator of sudden and immediate financial exposure.

The data set for the analysis was obtained from the leading Slovak corporate analytical agency CRIF - Slovak Credit Bureau, s. r. o., and comprised detailed financial statements of a large proportion of Slovak enterprises with activities falling into all business sectors of the Slovak economy. The data set involved all the four legal forms of enterprises common in Slovakia (i.e. v.o.s. - general partnership, k.s. - limited partnership, s.r.o. - private limited 
company, a.s. - joint-stock company) and related to a range of 5 fiscal periods: from 2009 to 2013. The fact that the data set did not originate as a random drawing from the population of Slovak enterprises and constitutes just a selective sub-sample poses an obstacle to making a generalization of the findings and statistical inference. Nonetheless, this is a troubling complication of (almost) every study of this kind.

In the process of verification, the classification horizon of one year was applied in estimating the coefficients of the discriminant function, similarly as was done in Altman (1968, 1983). This means that the classification of enterprises into those in financial distress and those financially non-distressed depended on their financial statements released in the next annual reporting period. These financial statements were screened for meeting all the three specified criteria of financial distress and this resulted in separating enterprises into two groups for the purpose of estimation. Furthermore, in the time period of 5 years from 2009 to 2013 there are a total of four sub-periods spanning two consecutive years. This was permitted to perform estimations (or to re-estimate the Z-score model) sequentially for the data derived from financial statements dated to 2009, 2010, 2011 and 2012 (whilst classification of enterprises was based on financial statements dated to 2010, 2011, 2012 and 2013, respectively). Only enterprises which were in the initial year found non-distressed were included in the data sample used and their distress behaviour was tracked. It makes sense only to predict if a non-distressed enterprise runs into financial distress the next year or later, and the situation that a distressed enterprise remains in financial distress is not of interest and is, to a degree, difficult to predict. The diffusion of financial distress over the five-year period for initially non-distressed enterprises in the individual years is described in Table 1.

Table 1. Numbers of non-distressed and distressed enterprises used in the verification analysis related to the individual initial years 2009-2012

\begin{tabular}{|c|c|c|c|c|c|c|}
\hline \multirow{2}{*}{ Initial year } & \multirow{2}{*}{ Enterprises } & \multicolumn{5}{|c|}{ Year } \\
\hline & & 2009 & 2010 & 2011 & 2012 & 2013 \\
\hline \multirow[t]{2}{*}{2009} & $\begin{array}{l}\text { Non-distressed: } \\
\text { total } \%\end{array}$ & $\begin{array}{c}2414 \\
(100 \%)\end{array}$ & $\begin{array}{c}2193 \\
(91.85 \%)\end{array}$ & $\begin{array}{c}2102 \\
(87.08 \%)\end{array}$ & $\begin{array}{c}2043 \\
(84.66 \%)\end{array}$ & $\begin{array}{c}1989 \\
(82.39 \%)\end{array}$ \\
\hline & $\begin{array}{l}\text { Distressed: } \\
\text { total \% }\end{array}$ & NA & $\begin{array}{c}221 \\
(9.15 \%)\end{array}$ & $\begin{array}{c}312 \\
(12.92 \%)\end{array}$ & $\begin{array}{c}371 \\
(15.37 \%)\end{array}$ & $\begin{array}{c}425 \\
(17.61 \%)\end{array}$ \\
\hline \multirow[t]{2}{*}{2010} & $\begin{array}{l}\text { Non-distressed: } \\
\text { total } \%\end{array}$ & & $\begin{array}{l}19490 \\
(100 \%)\end{array}$ & $\begin{array}{c}17078 \\
(87.62 \%)\end{array}$ & $\begin{array}{c}15995 \\
(82.07 \%)\end{array}$ & $\begin{array}{c}15485 \\
(79.45 \%)\end{array}$ \\
\hline & $\begin{array}{l}\text { Distressed: } \\
\text { total \% }\end{array}$ & & NA & $\begin{array}{c}2412 \\
(12.38 \%)\end{array}$ & $\begin{array}{c}3495 \\
(17.93 \%)\end{array}$ & $\begin{array}{c}4006 \\
(20.55 \%)\end{array}$ \\
\hline \multirow[t]{2}{*}{2010} & $\begin{array}{l}\text { Non-distressed: } \\
\text { total } \%\end{array}$ & & & $\begin{array}{l}27920 \\
(100 \%)\end{array}$ & $\begin{array}{c}24293 \\
(87.01 \%)\end{array}$ & $\begin{array}{c}23086 \\
(82.69 \%)\end{array}$ \\
\hline & $\begin{array}{l}\text { Distressed: } \\
\text { total \% }\end{array}$ & & & NA & $\begin{array}{c}3627 \\
(12.99 \%)\end{array}$ & $\begin{array}{c}4834 \\
(17.31 \%)\end{array}$ \\
\hline \multirow[t]{2}{*}{2011} & $\begin{array}{l}\text { Non-distressed: } \\
\text { total } \%\end{array}$ & & & & $\begin{array}{l}43068 \\
(100 \%)\end{array}$ & $\begin{array}{c}37578 \\
(87.25 \%)\end{array}$ \\
\hline & $\begin{array}{l}\text { Distressed: } \\
\text { total \% }\end{array}$ & & & & $\mathrm{NA}$ & $\begin{array}{c}5490 \\
(12.75 \%)\end{array}$ \\
\hline
\end{tabular}


This table gives an insight into the distress behaviour of Slovak enterprises. For the first initial year 2009, the sample size of enterprises was rather low in comparison to the other three initial years. Also the progression of financial distress among the 2,414 enterprises marked in 2009 as non-distressed in the next few years appears somewhat delayed as when compared to the propagation of financial distress for non-distressed companies in the initial years 2010, 2011 and 2012. The different pattern of an array of financial distress may be directly related to the global economic downturn of 2008-2009. In Table 1, the entries in the first two consecutive years for each initial year are highlighted to indicate a data sample utilized in the re-estimation of the Z-score model (respecting the classification horizon of one year).

Despite the intention to emulate Altman's methodological procedure as far as possible, there were necessarily some unavoidable deviations following the preceding discussion. They encompass the redefinition of "failed" enterprises with respect to the formulated definition of financial distress or the mismatch present between 1946-1965 US financial items and 2009-2013 Slovak financial items. An important diversion from Altman's methodology is in using the entire dataset available for each initial year (as declared in Table 1) and splitting it into a training sample and a test sample in the proportion of $75 \%$ to $25 \%$. Whilst the training sample served in the process of the re-estimation of the Z-score model, the assessment of predictive accuracy stipulated use of both the training and test sample. Unless clearly indicated and stated otherwise, the descriptive information and results presented in the ensuing tables pertain to the full sample of enterprises for a given initial year. Altman $(1968,1983)$ used the pooled sample of "failed" enterprises gathered over the entire 20-year period (obviously in order to increase the number of effective observations).

Altman $(1968,1983)$ used the computational and applicational variation of discriminant analysis as implemented in the FORTRAN codes of Cooley, Lohnes (1962, Chapters 6-7). In order to ensure some degree of comparability with his results, this procedure was obeyed to detail and implemented in program $\mathrm{R}$ using the codes compiled by one of the authors (R Core Team 2013). The analysis was entirely affected by this program and the achieved results are communicated in both tabular and graphical format. As in Altman $(1968,1983)$, the discriminant function was specified following the linear classification rule (i.e. LDA) in a usual way without an intercept, yet the cut-off value for discriminant scores that accompanies the classification rule was determined additionally so that a suitably chosen measure of training error was minimized. This goes in the wake of the procedure taken by Altman himself. The analysis was undertaken with the use of a statistical technique of LDA that depends upon a number of statistical assumptions (cf. e.g. Balcaen, Ooghe 2006: 67; Sun et al. 2014: 43). Some discussion may be held on this topic (concerning their actual necessity or validity), yet what matters in a classification problem is the ultimate prediction accuracy of the model built for classification and, in consequence, whether these statistical assumptions are indeed satisfied is not relevant to the analysis and its results. This is one of the two reasons why the validity of the statistical assumptions underlying the correct use of LDA was not scrutinized. This is the other reason to investigate the capability of Altman's Z-score model to predict financial distress of Slovak enterprises rather than building a completely new model. 
The results of re-estimating the Z-score model are displayed in Table 2. For each of the four initial years, Table 2 displays the coefficient values of the estimated discriminant function and the corresponding cut-off value allowing discrimination between financially distressed and non-distressed enterprises. Together with the coefficients and cut-offs answering to both the original and revised Altman's Z-score model are displayed for convenience. However, they differ from those reported with formulas (1) and (2) as all the discriminant coefficients in Table 2 are normalized to unit norm. This warrants comparability, and the cut-off values are re-calculated accordingly. It is questionable as to whether the discriminant coefficients should be required to possess the virtue of economic interpretability or they should be treated as a black-box ingredient of a classification model. Distractingly, the discriminant coefficient on $\mathrm{X} 4$ ' in each re-estimated Z-score model is very close to zero and the discriminant coefficients on X5 for three re-estimated Z-score models have a negative sign, though being close to zero. Though apparently being a concern in model building, it is not troubling here as now only the Z-score model is refitted to a new setting. It is then comprehensible that the data used with this re-estimation may have an internal structure different from the one incorporated in Altman's data. There are discernible differences between the coefficients and cut-offs of the individual models and there are also some trending features for the re-estimated models. One might establish that over the period of four years, from 2009 to 2012, the predictor financial indicators X1 and X3 rose in classification importance, whilst the classification power of X2 diminished. The low coefficient values on $\mathrm{X} 4$ ' presumably result from an immensely high level of variability particular of this prediction variable. In all probability, Altman $(1968,1983)$ operated with a "well-behaved" sample of 66 US enterprises where the ratio of market/book value of equity to book value of debt did not attain values dispersed over a large interval.

The cut-off values of the re-estimated Z-score models were not determined à la Altman $(1968,1983)$ who minimized misclassifications in a rather trial-and-error way, but a more general approach was employed instead. Following e.g. Begley et al. (1996) or Wu et al. (2014), the cut-off value was chosen so that the sum of Type I error and Type II error rates was minimal. Whilst Type I error comes from classifying a distressed enterprise as non-distressed, Type II error emerges with classifying a non-distressed enterprise as distressed. The

Table 2. Normalized discriminant coefficients and cut-off values of the re-estimated and original Z-score models

\begin{tabular}{ccccccc}
\hline \multirow{2}{*}{ Variable } & \multicolumn{3}{c}{ Re-estimated Z-score model } & \multicolumn{2}{c}{ Altman's model } \\
\cline { 2 - 7 } & 2009 model & 2010 model & 2011 model & 2012 model & 1968 original $^{\dagger)}$ & 1983 revised $\left.^{\dagger}\right)$ \\
\hline $\mathrm{X} 1$ & 0.345 & 0.459 & 0.588 & 0.701 & 0.303 & 0.206 \\
\hline $\mathrm{X} 2$ & 0.936 & 0.875 & 0.726 & 0.096 & 0.354 & 0.244 \\
\hline $\mathrm{X} 3$ & 0.016 & 0.156 & 0.356 & 0.706 & 0.834 & 0.895 \\
\hline $\mathrm{X} 4^{\prime}$ & $\left.0.000^{*}\right)$ & $\left.0.000^{*}\right)$ & $\left.0.000^{*}\right)$ & $0.000^{*}$ & 0.152 & 0.121 \\
\hline $\mathrm{X} 5$ & 0.073 & -0.005 & -0.010 & -0.005 & 0.253 & 0.287 \\
\hline Cut-off & 0.349 & 0.358 & 0.225 & 0.131 & 0.458 & 0.354 \\
\hline
\end{tabular}

Note: ${ }^{\dagger)}$ The coefficients are normalized to unit norm so as to induce comparability, and the cut-off values are adjusted accordingly as well. ${ }^{*}$ These coefficients are not nil. 
error rates are then determined as the proportions of Type I error or Type II error events to the number of distressed or non-distressed enterprises, respectively. For simplification, in line with Altman, Hotchkiss (2006: 244) a single value was considered as the cut-off, discarding thus the role of the grey area. The classification is simplified into considering an enterprise certainly distressed for a lower Z-score value and surely non-distressed for a greater $Z$-score value than the specified cut-off. For this reason, the cut-offs 0.458 and 0.354 for both Altman's Z-score models answer to the lower boundaries of the grey area, viz. 1.81 and 1.23. Enterprises falling otherwise with their Z-scores into the grey area are given the benefit of the doubt, wherein they are considered as non-distressed.

A more detailed geometrical analysis of the normalized discriminant coefficients suggests that great similarity is unsurprisingly observed for both the original and revised Altman's Z-score models and is similar to the re-estimated Z-score models corresponding to the initial years 2009, 2010 and 2011. The re-estimated Z-score model related to the initial year 2012 deviates from either of the two groups. This analysis goes for reasons of space unreported in the paper.

For each initial year, a total of three Z-score models were inspected for their predictive behaviour assessed in respect of a one-year classification horizon (the outcome of which is reported in Tables 3 and 4) and in respect to various classification horizons (the results of which are shown in Fig. 1).

Separately for the respective training and test sample in the four initial years, Table 3 summarizes the classification accuracy of both the original and revised Altman's Z-score models and of the re-estimated Z-score model. Using the overall accuracy (the total pro-

Table 3. Classification accuracy of the re-estimated and Altman's Z-score models

\begin{tabular}{|c|c|c|c|c|c|c|c|}
\hline \multirow{2}{*}{$\begin{array}{l}\text { Initial } \\
\text { year }\end{array}$} & \multirow{2}{*}{$\begin{array}{c}\% \text { of correctly } \\
\text { classified } \\
\text { enterprises }\end{array}$} & \multicolumn{2}{|c|}{$\begin{array}{c}1968 \text { original } \\
\text { Altman's model }\end{array}$} & \multicolumn{2}{|c|}{$\begin{array}{c}1983 \text { revised } \\
\text { Altman's model }\end{array}$} & \multicolumn{2}{|c|}{$\begin{array}{l}\text { Re-estimated } \\
\text { Z-score model }\end{array}$} \\
\hline & & $\begin{array}{l}\text { Training } \\
\text { sample }\end{array}$ & $\begin{array}{c}\text { Test } \\
\text { sample }\end{array}$ & $\begin{array}{l}\text { Training } \\
\text { sample }\end{array}$ & $\begin{array}{c}\text { Test } \\
\text { sample }\end{array}$ & $\begin{array}{l}\text { Training } \\
\text { sample }\end{array}$ & $\begin{array}{c}\text { Test } \\
\text { sample }\end{array}$ \\
\hline \multirow{3}{*}{2009} & Overall & $77.89 \%$ & $79.01 \%$ & $82.42 \%$ & $83.14 \%$ & $61.53 \%$ & $60.33 \%$ \\
\hline & Non-distresses & $81.69 \%$ & $81.60 \%$ & $87.71 \%$ & $87.25 \%$ & $60.04 \%$ & $58.47 \%$ \\
\hline & Distresses & $40.00 \%$ & $53.57 \%$ & $29.70 \%$ & $42.86 \%$ & $76.36 \%$ & $78.57 \%$ \\
\hline \multirow{3}{*}{2010} & Overall & $76.99 \%$ & $78.21 \%$ & $80.45 \%$ & $80.55 \%$ & $56.26 \%$ & $56.93 \%$ \\
\hline & Non-distresses & $83.00 \%$ & $84.05 \%$ & $87.96 \%$ & $88.03 \%$ & $53.41 \%$ & $54.03 \%$ \\
\hline & Distresses & $34.44 \%$ & $36.82 \%$ & $27.31 \%$ & $27.53 \%$ & $76.45 \%$ & $77.45 \%$ \\
\hline \multirow{3}{*}{2011} & Overall & $76.81 \%$ & $76.15 \%$ & $79.45 \%$ & 79.32\% & $66.07 \%$ & $66.14 \%$ \\
\hline & Non-distresses & $82.64 \%$ & $82.47 \%$ & $87.08 \%$ & $87.42 \%$ & $66.04 \%$ & $66.38 \%$ \\
\hline & Distresses & $37.79 \%$ & $33.85 \%$ & $28.35 \%$ & $25.03 \%$ & $66.25 \%$ & $64.50 \%$ \\
\hline \multirow{3}{*}{2012} & Overall & $76.56 \%$ & $76.83 \%$ & $79.66 \%$ & $79.51 \%$ & $70.53 \%$ & $70.54 \%$ \\
\hline & Non-distresses & $82.04 \%$ & $82.38 \%$ & $86.75 \%$ & $86.84 \%$ & $72.92 \%$ & $72.78 \%$ \\
\hline & Distresses & $39.08 \%$ & $38.82 \%$ & $31.07 \%$ & $29.35 \%$ & $54.19 \%$ & $55.21 \%$ \\
\hline
\end{tabular}

Note: The best classification performance in terms of accuracy is highlighted in bold for each initial year sample and for each of the three accuracy rates presented. 
portion of correctly classified enterprises), the true negative rate (the proportion of nondistressed enterprises that are correctly classified as non-distressed), and true positive rate (the proportion of distressed enterprises that are assigned a correct classification of being distressed), the simplest, yet most informative, measures of predictions are made. As a matter of fact, these three proportions give a percentage of all correctly classified enterprises, non-distressed enterprises and distressed enterprises, respectively. It is worth noticing that the true negative rate is a complement of the Type II error rate to unity whereas true positive rate complements Type I error to unity. The best accuracy delivered for both the training and test sample for each initial year and for each group (all enterprises, non-distressed enterprises and distressed enterprises) is highlighted in bold. It transpires that the best predictive performance in terms of one-year prediction accuracy is uniformly attained by the revised Altman's Z-score model, whereas the re-estimated model classifies most accurately distressed enterprises. Therefore, if the goal is to classify correctly an arbitrary enterprise, the revised Altman's Z-score model should be the choice, but if the emphasis is placed on correct classifications of distressed enterprises, then the re-estimated Z-score model should be given preference.

The global predictive performance of the Z-score models may be further assessed and visualized by means of receiver-operating characteristic (ROC) curves. In order to conserve space, the ROC curves are not included in this presentation, and the information that they convey is a proxy for the area-under-curve (AUC) statistic that summarizes the predictive performance generated by a ROC curve for various choices of the cut-off value. The AUC statistics for the three Z-score models and for the four initial years are shown in Table 4 separately for the training and test sample. Again, the most favourable values are indicated in bold face and they point to the re-estimated Z-score model delivering comparatively the best predictive performance (which seems yet only slightly better than the predictive performance of the other two Z-score models). Each Z-score model attains only fair predictive performance.

Both Table 3 and Table 4 show decreasing trends in terms of classification accuracy and predictive performance of the three Z-score models. Although all the three Z-score models maintain almost identical classification accuracy or predictive performance for both the training and test sample (as usually for the test sample classification models have a

Table 4. AUCs of the re-estimated and Altman's Z-score models

\begin{tabular}{ccccccc}
\hline Initial year & \multicolumn{2}{c}{$\begin{array}{c}\text { 1968 original } \\
\text { Altman's model }\end{array}$} & \multicolumn{2}{c}{$\begin{array}{c}\text { 1983 revised } \\
\text { Altman's model }\end{array}$} & \multicolumn{2}{c}{$\begin{array}{c}\text { Re-estimated } \\
\text { Z-score model }\end{array}$} \\
\cline { 2 - 7 } & $\begin{array}{c}\text { Training } \\
\text { sample }\end{array}$ & $\begin{array}{c}\text { Test } \\
\text { sample }\end{array}$ & $\begin{array}{c}\text { Training } \\
\text { sample }\end{array}$ & $\begin{array}{c}\text { Test } \\
\text { sample }\end{array}$ & $\begin{array}{c}\text { Training } \\
\text { sample }\end{array}$ & $\begin{array}{c}\text { Test } \\
\text { sample }\end{array}$ \\
\hline 2009 & 0.708 & 0.632 & 0.701 & 0.625 & $\mathbf{0 . 7 4 0}$ & $\mathbf{0 . 7 3 6}$ \\
\hline 2010 & 0.649 & 0.626 & 0.639 & 0.616 & $\mathbf{0 . 7 1 0}$ & $\mathbf{0 . 7 0 3}$ \\
\hline 2011 & 0.636 & 0.650 & 00.624 & 0.639 & $\mathbf{0 . 7 0 8}$ & $\mathbf{0 . 7 1 5}$ \\
\hline 2011 & 0.642 & 0.640 & 0.631 & 0.632 & $\mathbf{0 . 6 8 4}$ & $\mathbf{0 . 6 7 3}$ \\
\hline
\end{tabular}

Note: The best classification performance in terms of AUC is highlighted in bold for each initial year sample. 
tendency to deteriorate), their predictive quality somewhat descends over the four initial years. This is especially seen for the true positive rates indicating that the ability of these $\mathrm{Z}$-score models to predict the distress condition of distressed enterprises diminishes. For the re-estimated $\mathrm{Z}$-score model this fall is about 22 percentage points.

Eventually, Figure 1 reports in a layout of six charts on the predictive behaviour of the three Z-score models that they achieve for various classification horizons. The models' predictive behaviour is measured and visualized with respect to classification accuracy of all enterprises (overall accuracy) and distressed enterprises (true positive rate). While the three charts in the first row of the layout show overall accuracy, the other three charts in the second row then display the true positive rate. The classification accuracies of the three Z-score models presented in Figure 1 are derived from the data sample pertaining to the initial year 2009 (see the numbers of non-distressed and distressed enterprises over the period from 2009-2013 in the first row of Table 1). The predictive behaviour for the other three initial years 2010, 2011 and 2012 is not reported here in the paper since it is very much the same. Each of the six charts shows how the classification accuracy of the Z-score model behaves with respect to different timings of predictions and to different classification horizons. For the predictions starting in 2009, the data sample of 2,414 enterprises being non-distressed in 2009 was used and their distress condition was predicted for 2010, 2011, 2012 and 2013, which implies the classification horizon of one year, two years, three years and four years, respectively. The predictions starting in 2010 related to the 2,193 enterprises that were non-distressed in 2010. The distress condition of these 2,193 enterprises was predicted for the next three years 2011, 2012 and 2013 implying a classification horizons of one, two and three years. This pattern was subsequently repeated for the starts in 2011 and 2012 and in each start predictions for the classification accuracy of each of the three Z-score models was evaluated and finally plotted in a respective chart in Figure 1. Not only does this design reveal the ability of the $\mathrm{Z}$-score models to retain their classification accuracy with respect to different classification horizons, but it also shows how the classification accuracy of the Z-score models react to the changing economic conditions that
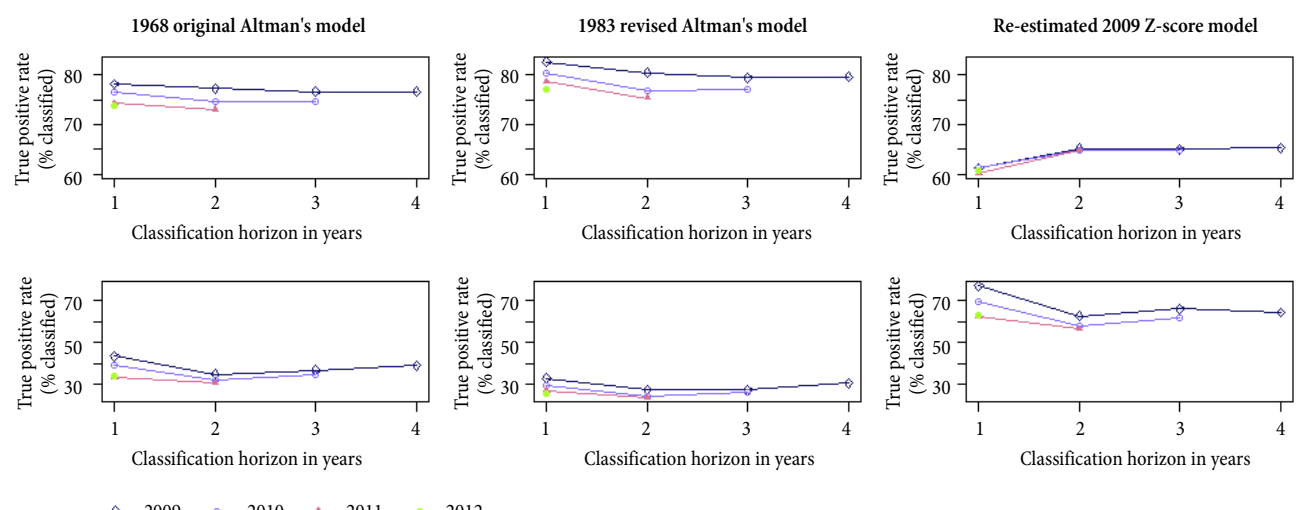

Fig. 1. Classification accuracy of the re-estimated and Altman's Z-score models for various classification horizons using the sample related to the initial year of 2009 
may have happened in the investigated time span of five years. The global economic crisis that demonstrated its effects mainly between 2007 and 2009 brought in some instability in the Slovak economic environment and was followed by a slow stabilization accompanied by a number of structural and legislative changes. Although the Slovak economy officially did not experience a recession, under scrutiny, all these factors revealed themselves in the period from 2009-2013 and also affected the business environment and the distress condition of Slovak enterprises. It is only understandable that this impacts the predictive capability of the Z-score models.

Though the patterns displayed in Figure 1 apply to the initial year 2009, the patterns for the other three initial years are almost identical. They afford to make three fairly general observations. First, the overall accuracy of both the original and revised Altman's Z-score model is for any classification horizon higher than that of the re-estimated Z-score model. Yet, the best classification performance in terms of true positive rates (i.e. the classification accuracy of distressed enterprises) is globally achieved by the re-estimated Z-score model. Second, the classification horizon does not seem to be a major factor that affects the classification accuracy of the Z-score models. There are some oscillations or signs of a trending behaviour in classification accuracy displayed in the individual charts of Figure 1, but they are virtually irrelevant and may not be given much attention. Lastly, the later the start of predictions, the lower is in general the classification accuracy of the Z-score models. This is especially true for the overall accuracy of the original and revised Altman's models and for the true positive rate of the re-estimated Z-score model.

\section{Conclusions and discussion}

In spite of the methodological uncertainties associated with employing Altman's Z-score model in predicting financial distress of Slovak enterprises, it looks that, to some degree, his model works and yields satisfactory predictive performance. This statement is at least valid for the sample of Slovak enterprises permitting the empirical verification of the model that was conducted in a setting of financial distress prediction and focused on the Slovak economic conditions. The warnings raised in the second section against the use of the $\mathrm{Z}$ score model seem to be unfounded since both formulations proposed by Altman $(1968,1983)$ or its re-estimated version function acceptably. Several reasons why the Z-score model is usable for predicting financial distress of Slovak enterprises may be identified and are compiled as follows:

- Firstly, the five financial indicators acting as the predictors in the model were chosen favourably so that they include one liquidity ratio (X1), two profitability ratios (X2 and X3), one leverage ratio (X4 or rather X4') and one activity ratio (X5). Since each partial sphere of corporate financial activity is represented by one or two financial indicators, financial difficulties presenting themselves in at least one partial sphere should be easily captured by the Z-score model and any sign of financial distress should, in theory, be easily mapped into a respective Z-score value. An enterprise in financial distress experiencing consistent operating losses faces the shrinking of current assets in relation to total assets, which touches on liquidity (captured by X1) 
and undergoes a decreasing earning power of its assets both in a given period and also on a cumulative basis (which is seized by X2 and X3). A financially distressed company on the verge of insolvency necessarily has debt well in excess of its equity regardless of whether equity is quantified by the market value or by the book value (this is embodied in X4 or X4'). Finally, the ability of such an enterprise to generate sales through its assets is lowered and a fall in sales might expectably ensue (which is then reflected in X5). All these five indicators have a sound economic justification and this quintet does represent a convenient instrument of identifying financial difficulties of enterprises in any economic environment and any period. It is not important therewith as to whether financial difficulties are understood in juridical terms and equalled with bankruptcy, or they are given a purely economic treatment and interpreted in general as financial distress.

- Second, the adopted definition of financial distress that is regarded as suitable for the Slovak economic conditions is in close relation to the five predictive financial indicators. The first prerequisite for a financially distressed enterprise that its equity be negative should be forecast directly by X4' and partly as well by X2. The second prerequisite that the EAT be negative is tied closely with $\mathrm{X} 3$ and the third prerequisite that the current ratio be lower than 1 is in a direct link with X1. When taken on a univariate basis, these four financial indicators should themselves be sufficient to indicate one aspect of the financial condition of a distressed enterprise. Therefore, with respect to the chosen and vindicated definition of financial distress, it is unsurprising that the model is fairly successful in predicting financial distress.

- Third, under the maxim "the simpler a model, the better", Altman's Z-score model is in the frame for theoretically good predictive performance. Balcaen, Oooghe (2006: 81) as well as Sun et al. (2014: 53) highlight the popularity of simpler bankruptcy prediction models thanks to their good classification abilities. The Z-score model works only on five financial indicators and is derived with the aid of LDA. Its conceptual simplicity underpinned with a well thought out choice of predictive financial indicators justified on economic grounds may be another reason for its comparative acceptable predictive performance even outside its home environment in a different time period.

One still may question another element of Altman's Z-score model and its importability to the Slovak economic conditions and this is the fact that it is employed to identify financial distress of enterprises using financial statements one year preceding the distressed condition. There is also the trend of including cash-flow variables into bankruptcy prediction models (Balcaen, Ooghe 2006: 80; Platt, H. D., Platt, M. B. 2006: 146), but these are not represented in the Z-score model. However, it has been established through empirical verification that common ratio indicators (such as those made use in the Z-score mode) reveal a good classification capacity the year immediately prior to bankruptcy (which is consistent with the classification horizon of one year of the Z-score model), whilst cash-flow variables would need two or three years prior to bankruptcy to detect the distress condition (cf. Altman, Hotchkiss 2006: 251). There is not much left to doubt about the potential of the five financial ratios in the $\mathrm{Z}$-score model to predict financial distress. 
It further transpires that in terms of classification accuracy the Z-score model applied in the Slovak economic conditions can be trustworthy and compete with its application in the home US environment. When transcribing the classification accuracies of the Z-score model portrayed in Figure 1 and the analogous figures for the initial years 2010-2012 into a tabular format, the result is the summary presented in Table 5. The classification accuracies of the 1968 Altman's original model, the 1983 Altman's revised model and the re-estimated Z-score models that were found for the data sample of Slovak enterprises utilized in the paper are appended by the one-year classification accuracies that the 1968 Altman's original model revealed for a sample of US enterprises. These additional classification accuracies included for comparison purposes in Table 5 are those reported by Altman, Hotchkiss (2006: 244).

Table 5. Classification accuracy of the Z-score models for the sample of Slovak enterprises and for the US economy

\begin{tabular}{|c|c|c|c|c|c|}
\hline \multirow{2}{*}{\multicolumn{2}{|c|}{ Z-score model and data }} & \multicolumn{4}{|c|}{ Years prior to distress } \\
\hline & & 1 & 2 & 3 & 4 \\
\hline \multirow{6}{*}{$\begin{array}{c}\text { Slovak } \\
\text { 2009-2013 } \\
\text { data }\end{array}$} & 1968 Altman's original & $77.6-78.2 \%$ & $74.7-76.6 \%$ & $73.1-74.3 \%$ & $73.9 \%$ \\
\hline & 1983 Altman's revised & $79.4-82.6 \%$ & $76.8-80.4 \%$ & $75.3-78.6 \%$ & $77.2 \%$ \\
\hline & 2009 re-estimated & $61.2-65.2 \%$ & $61.3-65.0 \%$ & $60.2-64.8 \%$ & $60.8 \%$ \\
\hline & 2010 re-estimated & $56.4-56.8 \%$ & $56.7-57.5 \%$ & $57.8 \%$ & NA \\
\hline & 2011 re-estimated & $66.1-66.4 \%$ & $65.6 \%$ & NA & NA \\
\hline & 2012 re-estimated & $70.5 \%$ & NA & NA & NA \\
\hline US 1968 data & \multirow{4}{*}{1968 Altman's original } & $88 \%$ & NA & NA & NA \\
\hline US 1969-1975 data & & $75 \%$ & NA & NA & NA \\
\hline US 1976-1995 data & & $78 \%$ & NA & NA & NA \\
\hline US 1997-1999 data & & $84 \%$ & NA & NA & NA \\
\hline
\end{tabular}

Note: If applicable, the classification accuracy is reported as a range of percentages. The percentages for the US data are those reported by Altman, Hotchkiss (2006: 244).

It follows from Table 5 that both the 1968 Altman's original model and its 1983 revision provide quite reliable prediction rules of the distress status of Slovak enterprises not only one year preceding the distress condition but their prediction ability extends over a longer classification horizons. Understandably, accuracy tends to a decrease commensurate with prolongation of the classification horizon, yet the classification accuracy of the original and revised Altman's model displayed for the Slovak data sample for three or four years preceding the distress condition is comparable to the classification accuracy of the original Altman's model shown for the US 1969-1975 or 1976-1995 data. The revised Altman's model especially manifests good prediction performance with respect to overall classification accuracy. The Z-score models with re-estimated coefficients are not capable of classifying with a satisfactory level of accuracy, being positively outperformed by either of Altman's models with coefficients fitted for the US economy. This is only suggestive that the Z-score model is portable outside the domestic US environment and can be used under Slovak conditions. Nevertheless, as argued in the third section of the paper, if the ambition 
is to minimize the number of misclassifications of financially distressed enterprises, which is in fact a standard and usual aim of financial distress prediction, then it is suitable to reestimate the coefficients of the Z-score model.

All in all, the conclusion is thus that Altman's bankruptcy formula is suitable for Slovak economic conditions and useful for predicting financial distress of Slovak enterprises. This ultimate statement naturally does not mean that Altman's model cannot be improved on e.g. by accommodating an additional set of predictive financial indicators or by using a different classification technique and this quest goes beyond the intentional scope of the paper. That said, there still are a good many directions for further research in financial distress prediction of Slovak enterprises. One direction is connected to the presumable non-existence of a universal definition of financial distress applicable to the Slovak economic conditions. Such a definition would have to capture and reflect all the aspects of the financial difficulties that Slovak enterprises must face in their business activities. In addition, its introduction would also necessitate careful economic reasoning supported with a detailed analysis of the distress condition of Slovak enterprises. It is not impossible that it might be based on information reported in financial statements from several fiscal years.

\section{Funding}

This work was supported by Vedecká grantová agentúra Ministerstva školstva, vedy, výskumu a športu Slovenskej republiky a Slovenskej akadémie vied under Grants [\# 1/0647/14 and \# 1/0554/16].

\section{References}

Altman, E. I. 1968. Financial ratios, discriminant analysis and the prediction of corporate bankruptcy, The Journal of Finance 23(4): 583-609. http://doi.org/10.1111/j.1540-6261.1968.tb00843.x

Altman, E. I. 1983. Corporate financial Distress: a complete guide to predicting, avoiding, and dealing with bankruptcy. 1st ed. New York: Wiley.

Altman, E. I.; Hotchkiss, E. 2006. Corporate financial distress and bankruptcy: predict and avoid bankruptcy, analyze and invest in distressed debt. 3rd ed. New York: Wiley.

http://doi.org/10. 1002/9781118267806

Altman, E. I. 2013. Predicting financial distress of companies: revisiting the Z-score and ZETA ${ }^{\circledR}$ models, Chapter 17 in A. R. Bell, C. Brooks, M. Prokopczuk (Eds.). Handbook of research methods and applications in empirical finance. Glos, UK: Edward Elgar Publishing. http://doi.org/10.4337/ 9780857936097

Altman, E. I.; Haldeman, R. G.; Narayanan, P. 1977. ZETA ${ }^{\mathrm{mw}}$ analysis: a new model to identify bankruptcy risk of corporations, Journal of Banking and Finance 1(1): 29-54. http://doi.org/10. 1016/0378-4266(77)90017-6

Altman, E. I.; Iwanicz-Drozdowska, M.; Laitinen, E. K.; Suvas, A. 2014. Distressed firm and bankruptcy prediction in an international context: a review and empirical analysis of Altman's Z-Score model, in International Risk Management Conference 2014, Seventh Edition "The Safety of the Financial System: From Idiosyncratic to Systemic Risk", 23-24 June 2014, Warsaw, Poland.

Asquith, P.; Gertner, R.; Scharfstein, D. 1994. Anatomy of financial Distress: an examination of junkbond issuers, The Quarterly Journal of Economics 109(3): 625-658. http://doi.org/10.2307/ 2118416 
Balcaen, S.; Ooghe, H. 2006. 35 years of studies on business failure: an overview of the classic statistical methodologies and their related problems, The British Accounting Review 38(1): 63-93. http://doi.org/10.1016/j.bar.2005.09.001

Begley, J.; Ming, J.; Watts, S. 1996. Bankruptcy classification errors in the 1980s: an empirical analysis of Altman's and Ohlson's models, Review of Accounting Studies 1(4): 267-284. http:// doi.org/10.1007/BF00570833

Chrastinová, Z. 1998. Metódy hodnotenia ekonomickej bonity a predikcie finančnej situácie polnohospodárskych podnikov. Bratislava: Výskumný ústav ekonomiky polnohospodárstva a potravinárstva (in Slovak).

Cooley, W. W.; Lohnes, P. R. 1962. Multivariate procedures for the behavioral sciences. New York: Wiley.

Delina, R.; Packová, M. 2013. Validácia predikčných bankrotových modelov v podmienkach SR, E\&M Ekonomie a Management 16(3): 101-113 (in Slovak).

Dimitras, A. I.; Zanakis, S. H.; Zopounidis, C. 1996. A survey of business failures with an emphasis on prediction methods and industrial applications, European Journal of Operational Research 90(3): 487-513. http://doi.org/10.1016/0377-2217(95)00070-4

Dopravný podnik mesta Prešov. 2015. Výročná správa za rok 2014. Annual Report. Lubotice: Dopravný podnik mesta Prešov, a. s. (in Slovak).

Gilbert, L. R.; Menon, K.; Schwartz, K. B. 1990. Predicting bankruptcy for firms in financial distress, Journal of Business Finance \& Accounting 17(1): 161-171. http://doi.org/10.1111/j.1468-5957. 1990.tb00555.x

Grice, J. S.; Dugan, M. T. 2001. The limitations of bankruptcy prediction models: some cautions for the researcher, Review of Quantitative Finance and Accounting 17(2): 151-166. http://doi.org/ 10.1023/A:1017973604789

Grice, J. S.; Ingram, R. W. 2001. Tests of the generalizability of Altman's bankruptcy prediction model, Journal of Business Research 54(1): 53-61. http://doi.org/10.1016/S0148-2963(00)00126-0

Gurčík, L. 2002. G-index - metóda predikcie finančného stavu polnohospodárskych podnikov, Agricultural Economics (Zemédělská Ekonomika) 48(8): 373-378 (in Slovak).

Hillier, D.; Ross, S. A.; Westerfield, R. A.; Jaffe, J.; Jordan, B. D. 2010. Corporate finance. European ed. Berkshire: McGraw-Hill.

Hrdý, M.; Šimek, B. 2012. Valuation of the company in financial distress, E\&M Ekonomie a Management 15(4): 121-133.

I.S.D.D. plus 2014. Výročná správa za rok 2013. Annual Report. Bratislava: I.S.D.D. plus, s. r. o. (in Slovak).

Kalouda, F.; Vaníček, R. 2013. Alternative bankruptcy models for CR conditions (concept and empirical verification), in M. Čulík (Ed.). Financial Management of Firms and Financial Institutions. 9th International Scientific Conference Proceedings, Part I. Ostrava: VŠB -Technická univerzita Ostrava, 316-324.

Király, P.; Kotulič, R.; Smolko, M. 2015. Softvér na finančno-ekonomickú analýzu firmy SOFINA Version 3.01. Software. (in Slovak).

Kopta, D. 2009. Possibilities of financial health indicators used for prediction of future development of agricultural enterprises, Agricultural Economics (Zemědělská Ekonomika) 55(3): 111-125.

Kotulič, R.; Király, P.; Rajčániová, M. 2010. Finančná analýza podniku. 2 ed. Bratislava: Iura Edition. (in Slovak).

Kúpele Trenčianske Teplice. 2012. Výročná správa 2011. Annual Report. Kúpele Trenčianske Teplice, a. s, Trenčianske Teplice (in Slovak).

Li, J. F. 2012. Prediction of corporate bankruptcy from 2008 through 2011, Journal of Accounting and Finance 12(1): 31-41. 
Ministerstvo hospodárstva Slovenskej republiky. 2014. Analýza stavu malého a stredného podnikania. Analytical Document Bratislava. Ministerstvo hospodárstva Slovenskej republiky (in Slovak).

Platt, H. D.; Platt, M. B. 2006. Understanding differences between financial distress and bankruptcy, Review of Applied Economics 2(2): 141-157.

Pitrová, K. 2011. Possibilities of the Altman Zeta model application to Czech firms; E\&M Ekonomie a Management 14(3): 66-76.

Púchovský mäsový priemysel. 2014. Výročná správa za rok 2013. Annual Report. Púchovský mäsový priemysel, a. s., Púchov (in Slovak).

R Core Team. 2013. $R$ : a language and environment for statistical computing (Version 3.0.2). (Software).

Slovak Business Agency. 2014. Analýza ukazovatelov finančnej výkonnosti malých a stredných podnikov $v$ rokoch 2008-2012. Analytical Document. Slovak Business Agency, Bratislava (in Slovak).

Slovak Business Agency. 2015. Analýza ukazovatelov finančnej výkonnosti malých a stredných podnikov v roku 2013. Analytical Document. Slovak Business Agency, Bratislava (in Slovak).

Stolárik, M. 1996. Meranie finančného zdravia firiem, Hospodárske noviny, 3 March 1996, p. 19 (in Slovak).

Strachotová, A. 2012. Finančná pozícia nefinančných podnikov, Biatec 20(1): 2-9 (in Slovak).

Sun, J.; Li, H.; Huang, Q.-H.; He, K.-Y. 2014. Predicting financial distress and corporate failure: a review from the state-of-the-art definitions, modeling, sampling, and featuring approaches, KnowledgeBased Systems 57: 41-56. http://doi.org/10.1016/j.knosys.2013.12.006

Šnircová, J. 1997. Možnosti prognózovania finančnej situácie podnikov v slovenskej ekonomike, Biatec 5(4): 15-22 (in Slovak).

Štrangfeldová, J. 2012. Finančno-ekonomická analýza ex ante v lekárni, Poradca lekárnika 8(10): 13-16 (in Slovak).

Taffler, R. J. 1984. Empirical models for the monitoring of UK corporations, Journal of Banking and Finance 8(2): 199-227. http://doi.org/10.1016/0378-4266(84)90004-9

Wu, Y.; Gaunt, C.; Gray, S. 2010 A comparison of alternative bankruptcy prediction models, Journal of Contemporary Accounting \& Economics 6(1): 34-45. http://doi.org/10.1016/j.jcae.2010. 04.002

Zákon č. 7/2005 Z. z. o konkurze a reštrukturalizácii a o zmene a doplnení niektorých zákonov v zn. n. p. [Bankruptcy Act No. 7/2005 Coll.] (in Slovak).

Zalai, K. 1997. Význam a metódy prognózovania finančnej situácie firmy, Biatec 5(3): 15-22 (in Slovak).

Zalai, K. 2000. Osobitosti prognózovania finančného vývoja slovenských podnikov, Biatec 8(1): 14-16 (in Slovak).

Martin BOĎA (Slovakia, 1984) orientates his scientific work to applications of a wider spectrum of quantitative methods in finance and economics. His scientific preparation is founded in the area of economics and finance (finance, banking and investment; tourism) and of quantitative methods (mathematical statistics and financial mathematics; probability and mathematical statistics). His professional orientation may be broken into three chief fields: (1) efficiency measurement in banking, (2) applications of data envelopment analysis in finance, (3) financial risk measurement. Martin Boda is employed as a lecturer at the Faculty of Economics of Matej Bel University in Banská Bystrica, Slovakia.

Vladimír ÚRADNÍČEK (Slovakia, 1963) has his scientific work continually directed towards application of quantitative methods in the area of finance, corporate economics and management. His scientific and professional activities are targeted at four compact parts: (1) pricing of financial derivatives, (2) financial mathematics and financial analytics, (3) corporate financial health prediction, and (4) investigation of economic sustainability and convergence issues. Vladimír Úradníček currently occupies the positon of Vice-Dean at the Faculty of Economics of Matej Bel University in Banská Bystrica, Slovakia. 